\title{
Al-Qur'an Dalam Perspektif Masyarakat Islam Kejawen dan Implikasinya dalam Kehidupan Praksis
}

\section{(Studi Komunitas Bonokeling di Desa Pekuncen Kecamatan Jatilawang Kabupaten Banyumas)}

\author{
Intan Novelia \\ IAIN Purwokerto \\ Jl. A Yani N0. 40A \\ Purwokerto Utara \\ Email; intannovelia4217@gmail.com
}

\begin{abstract}
Abstrak
Artikel ini membahas tentang Al-Quran dalam perspektif masyarakat Islam Kejawen dan implikasinya dalam kehidupan praksis. Penelitian ini merupakan jenis penelitian lapangan dengan teori konstruksi sosial dari Peter L Berger yang menekankan pada makna dan penafsiran bersama yang dikonstruksi dalam jaringan masyarakat. Hasil penelitian menunjukkan bahwa komunitas Islam kejawen Bonekeling yang sinkretis ini memiliki pandangan dan keyakinan tersendiri mengenai Al-Qur'an, bukan sebagai pedoman hidup seperti layaknya umat Islam, tapi sebagai kitab suci yang nati akan ditanyakan malaikat di alam kubur. Pandangan tersebut berimplikasi terhadap kehidupan mereka. Mereka memahamai ajaran Islam dalam Al-Qur'an, seperti shalat dan aurat, berbeda dengan umat Islam pada umumnya. Shalat sebagai sembahyang dimaknai sebagai berbuat baik kepada sesama manusia, rukun, saling tolong menolong dan menjaga tradisi nenek moyang mereka. Sementara tentang aurat, mereka tidak memiliki batasan-batasan anggota tubuh yang wajib ditutup, tetapi mereka menekankan bahwa yang terpenting adalah memperbaiki diri terlebih dahulu agar menjadi manusia yang baik.
\end{abstract}

Kata Kunci: Islam Kejawen, Al-Qur'an, Shalat, Aurat

\begin{abstract}
Abstack
This article discusses the Qu'ran from the perspective of the Kejawen Islamic community and its implications in the lives of praxis. This research is a type of field research with the theory of social construction from Peter L. Berger that emphasizes the meaning and a shared-interpretation constructed in community networks. The results showed that the syncretic Kejawen Bonekeling Islamic community had its own views and beliefs about the Qur'an, not as a way of life like Muslims, but as a holy book that would be asked by angels in the grave. This view has implications for their lives. They understand the teachings of Islam in the Qur'an, such as prayer and aurat, different from Muslims in general. Prayer as sembahyang is interpreted as doing good to fellow human beings, getting along well, helping each other to help and protect the traditions of their ancestors. While
\end{abstract}


regarding aurat, they do not have boundaries that must be covered, but they emphasize that the most important thing is to improve themselves first to become a good human being.

\section{Key Words: Javanese Islam, The Qur'an, Salat, Aurat}

\section{A. Pendahuluan}

$\mathrm{U}$ mat Islam di seluruh dunia meyakini bahwa Al-Quran merupakan petunjuk kehidupan (way of life) yang absolut dan eternal (sālih li kulli zamān wa makān) (Muslim, 2018, p. 104). Al-Qur'an sebagai sebuah petunjuk bagi manusia, dipahami dan direspon secara berbeda oleh masayarakat. Perbedaan pemahaman dan respon ini merupakan bukti konkret bahwasannya AlQur'an merupakan kitab yang relevan dan mampu untuk survive sampai saat ini walau dalam kondisi budaya dan sosial masyarakat yang berbeda-beda (sālih li kulli zamān wa makān).

Di era pra Al-Qur'ān, masyarakat Arab telah terbiasa berhubungan dengan jin, sosok makhluk immaterial yang diciptakan Tuhan. Di dalam mencari inspirasinya, para sastrawan dan dukun bergantung pada jin yang diyakini dapat menangkap fenomena alam dan realitas gaib dari langit, sehingga para sastrawan dan dukun mampu memberikan informasi akurat tentang berita gaib mengenai peristiwa yang akan dialami seseorang di hari-hari mendatang. Al-Qur'an mengakomodir dan mereproduksi konsep wahyu yang merupakan fenomena aktual yang tak terpisah dari budaya Arab yang berkembang saat itu (Abu Zayd, 1993, p. 34). Oleh karena apabila tidak demikian, AlQur'an akan kehilangan daya magis dan relevansinya jika dalam budaya seperti itu AlQur'an hadir dengan wajah lain yang bertujuan untuk mengadili realitas, dengan asumsi budaya mereka sebagai budaya jahiliyah.

Dari para penyair Arab pra Al-Qur'an, Al-Qur'an mulai diminati banyak orang dan bahkan dijadikan way of life pandangan hidup masyarakat Arab saat itu, yang oleh Nasr Hamid kemudian disebut dengan peradaban teks (Hadarah al- Naș) (Abu Zayd, 1993, p. 9). Setiap menghadapi persoalan, Al-Qur'an selalu dijadikan rujukan utama dan pertama sebelum mengacu pada akal dan lainnya, yang dalam hal ini menurut Nasr Hamid, Al-Qur'anberada dalam fase membentuk budaya (al-marhalah al-takwiniyah) puasa ramadan dan ibadah haji merupakan bagian dari ritual masyarakat Arab pra AlQur'an kemudian diislamisasi, ${ }^{1}$ dan akhirnya menjadi ritual keagamaan khas Islam yang menjadi kewajiban umat Islam sepanjang masa.

${ }^{1}$ Menurut Isutzu, terdapat kontinuitas tertentu antara pandangan Qur'aniyah dengan pandangan dunia Arab. Karena itu, menurutnya, sangat tidak adil terhadap keduanya jika semangat Alqurandipandang bertentangan seratus persen dengan semangat pertama.Adopsi yang diambil Alquran 
Seiring dengan perkembangan sosial budaya yang begitu cepat, ternyata bentuk relasi Al-Qur'an dengan budaya lokal era Al-Qur'an ini, yang berposisi sebagai pembentuk budaya, tidak selamanya mendukung model purifikasi, sebab perkembangan sosial budaya yang begitu cepat merambah ke dalam jantung kehidupan umat Islam, bukan hanya menjadi kendala bagi kemurnian agama Islam, sebaliknya, umat Islam justru merasa membutuhkan perkembangan tersebut, sebab ajaran Islam model klasik yang melarang bid'ah atau inovasi ternyata tidak mampu memberikan solusi alternatif bagi kebutuhan material dan rasional manusia di masa-masa mendatang. Oleh karena itu, peradaban Arab klasik runtuh akibat kekakuan pemahaman, khususnya pada era belakangan atas relasi Islam dan budaya lokal, utamanya pasca abad pertengahan, dengan mengikuti model purifikasi dengan tanpa menghargai lokalitas atau budaya. Oleh karena itu, apabila ditinjau dari aspek sejarah, banyak para pendakwah Islam menyebarkan ajaran Islam yang bersumber dari Al-Qur'an dengan cara mengakulturasikannya dengan budaya lokal (Tajuddin, 2014, p. 367).

Selaras dengan pandangan tersebut penelitian ini mencoba menggali korelasi dari pandangan masyarakat Islam kejawen dengan menggunakan teori dari Peter L. Berger, bahwa, masyarakat merupakan fenomena dialektik dalam pengrtian, masyarakat adalah suatu produk dari manusia, dan sebaliknya manusia adalah suatu produk dari masyarakat (Berger, 1991, p. 3). Aktivitas dan kesadaran manusia telah memberikan sebuah bentuk kepada suatu masyarakat. Manusia sebagai subjek dari masyarakat memiliki standar-standar objektifis dalam menciptakan sebuah struktur sosial dan budaya. Realitas sosial tidak terpisah dari manusia. Pada sisi lain, di dalam masyarakatlah sebuah seseorang menjadi pribadi, ia memperoleh dan berpegang pada suatu identitas, dan ia melaksanakan berbagai kegiatan yang menjadi bagian kehidupannya, yang kemudian dapat dipastikan bahwa manusia adalah suatu produk dari masyarakat. Menurut Berger, kedua pernyataan di atas, bahwa masyarakat adalah produk manusia dan manusia adalah produk masyarakat, tidaklah berlawanan. Sebaliknya, keduanya menggambarkan sifat dialektik inhern dari fenomena yang ada di masyarakat. Dengan menggunakan kerangka teoritis tersebut, maka masyarakat akan bisa dipahami dalam kerangka-kerangka yang memadai relalitas empirisnya (Berger \& Luckman, 2012, p. 4).

\section{B. Profil dan Sistem Keyakinan Komunitas Bonokeling}

Komunitas Bonokeling merupakan sebuah kelompok keagamaan yang teletak di Kabupaten Banyumas tepatnya di desa Pekuncen Jatilawang. Komunitas merupakan

menurutnya tetap dalam kerangka perubahan, yakni dalam bentuk Islamisasi terhadap nilai-nilai lama masyarakat Arab pra Al-Qur'ān. (Izutsu, 1995, p. 111). 
sebuah kelompok yang masih mempertahankan religi Jawa. Komunitas Bonokeling ini meyakini terhadap roh dan leluhur. Mereka mempercayai bahwa roh para leluhur melindungi anak putu selain mereka mempercayai adanya Allah SWT yang mereka sebut Gusti Allah. Mereka beranggapan bahwa roh leluhur merupakan perantara dalam berhubungan dengan Tuhan.

Pembahasan mengenai Banyumas sebelum Islam tidak bisa dipisahkan dari sejarah dua kerajaan besar yang menguasai bumi Jawa, yaitu kerajaan Majapahit (Jawa Timur) dan Pajajaran (Jawa Barat) Alur Majapahit yang kemudian membentuk Banyumas bisa ditelusuri pada sejarah berdirinya Kadipaten Wirasaba I (abad 15). Sementara jalur kerajaan Pajajaran dapat ditemukan pada sejarah berdirinya Kadipaten Pasir luhur (abad 14-15). Setelah dua kerajaan besar tersebut, kerajaan- kerajaan di Jawa Tengah Bagian Timur (Demak, Pajang, dan Mataran) mengambil alih wilayah Banyumas dengan membangun kadipaten wirasaba II dan Kadipaten Banyumas (abad 16-19). Dengan demikian, Banyumas sebenarnya hanyalah merupakan kota kabupaten yang merupakan bagian dari, baik kerajaan majapahit, Pajajaran, maupun kerajaankerajaan di Jawa Tengah bagian Timur (Muttaqin, 2017, p. 5).

Desa Pekuncen yaitu desa dimana komunitas adat Bonokeling ini berada, mepunyai adat istiadat atau tradisi yang tidak dapat kita temukan di desa lain. Ritualritual tersebut antara lain seperti perlon dalam acara Sadran dengan acara 'Unggahan'. Selain itu, secara umum masyarakat Desa Pekuncen masih menunjukkan identitas Jawa atau budaya yang bercorak 'kejawen'. Hal ini bisa dilihat dalam suatu kegiatan kemasyarakatan menggunakan pakaian warna hitam, dengan memakai blangkon atau iket, beskap, dan bebet untuk bapak-bapak (laki-laki), sedangkan ibu-ibu (perempuan) menggunakan pakaian kebaya. Hal ini tampak terutama apabila masyarakat Desa Pekuncen mengadakan kegiatan ritual dan mempunyai hajat.

Religi Bonokeling ini secara esensinya memiliki kesamaan dengan tradisi keagamaan orang Jawa pada umumnya, seperti melakukan ziarah kubur pada bulan Ruwah dan melakukan puasa di bulan puasa dalam kalender Jawa. Keunikan dari komunitas Bonokeling ini hampir semua ritus keagamaannya berorientasi pada pemujaan pundhen atau makam Bonokeling. Tradisi-tradisi tersebut masih tetap dijaga hingga kini.

Salah satu ajaran yang disampaikan yakni orang-orang Islam diwajibkan berpuasa di Bulan Ramadhan, sehingga Bulan Ramadhan adalah bulan suci yang memiliki keistimewaan dan harus dimuliakan. Oleh sebab itu, setiap menjelang Bulan Ramadhan, Bonokeling mengumpulkan seluruh keturunannya untuk mengadakan acara menyambut datangnya bulan yang suci yaitu Bulan Ramadhan dengan doa dan dzikir kepada Allah SWT. Tata cara menyambut bulan Ramadhan yang dilakukan oleh Bonokeling dan 
keturunanya, semasa hidupnya, ternyata diteruskan oleh anak keturunannya hingga saat ini. Bonokeling sendiri setelah wafat dimakamkan di sekitar tempat tinggalnya (Desa Pekuncen, Kecamatan Jatilawang).

Sejarah dari komunitas Bonokeling ini sendiri ada beberapa versi yang kemudian banyak digunkan sebagai basis legitimasi struktur sosial tertentu kondisi budaya tertentu. Keberadaan Desa Pekuncen seringkali dikaitkan dengan satu nama tokoh yaitu Bonokeling. Namun sejarah mengenai kyai Bonokeling itu sendiri masih rancu karena memiliki banyak versi sehingga belum bisa dijelaskan. Meskipun dalam hal ini sebenarnya ada yang bisa untuk menjelaskan namun para tetua adat belum bisa memberikan informasi tersebut kepada masyarakat.

Cikal bakal Desa Pekuncen, berdasarkan keterangan informasi dari informan yaitu bapak Sumitro, yang ia sebut sebagai “Cerita Legenda Desa Pekuncen”. Legenda tersebut diceritakan oleh bapak Sumitro yang bisa penulis rangkum sebagai berikut :

"Pada zaman Kerajaan Hindu-Budha ada 2 orang tokoh berkelana di hutan dan sungai. Selama perjalanan melihat pohon besar berwarna merah dipinggir sungai. Karena penasaran salah satu tokoh menyuruh temannya supaya memetik buah tersebut, tetapi ternyata tidak enak, sehingga dianggap membohongi (nglombo) maka buah tersebut dinamakan buah Lo. Pohon buah tersebut tumbuh di pinggir sungai dan di wilayah pasir, sehingga diberi nama Sungai Lopasir (Kali Pasir). Kemudian kedua tokoh tersebut meneruskan perjalanan dari arah barat ke timur sampai kelelahan dan beristirahat di bawah pohon beringin. Di sekitar pohon beringin terdapat rawa (kedhung), sehingga desa tersebut di beri nama Desa Kedungwringin. Selanjutnya kedua tokoh meneruskan perjalanan lagi kearah selatan, melihat hutan yang dibatasi dengan pohon besar dan aneh karena pertumbuhannya. Adapun macam tumbuhan tersebut, ada yang diberi nama pohon Naga Sari, Cendana, Kepuh dan lainnya. Pohon itu mengelompok dan dikelilingi pohon Wergu dan Rotan (penjalin). Maka bila di dalam hutan tersebut ada pohon yang tumbang masih diyakini akan ada peristiwa, sehingga hutan di sengker (dilindungi), tidak ada yang boleh menebang pohon di hutan tersebut (dikunci), yang kemudian diberi nama dukuh Kuncen (Purwana, 2015, p. 61).

Desa Kedungwringin kedatangan dua orang tokoh lagi, tetapi yang satu menempati dukuh Kuncen yang bernama Bonokeling dan menanam cikal (kayu agung). Kemudian cikal tersebut diluruskan satu dengan yang lain tidak papak (rajin), sehingga dukuh tersebut yang tadinya diberi nama Dukuh kuncen karena tidak papak dinamakan Dukuh Pekuncen. Setelah itu, datang lagi seorang tokoh ke Dukuh Pekuncen dan akhirnya ketiga tokoh tersebut merencanakan berani. Selanjutnya mereka membuka hutan yang disengkar (dilindungi).

Mereka mendirikan bangunan secara tradisional yang disebut kedaton. Ketiga tokoh tersebut massing-massing mempunyai ide antara lain: (a) memutuskan membuat kedaton, (b) menggambar kedaton, dan (c) melaksnakan pembuataan kedaton. Kedaton yang dibangun bentuknya joglo, atap terbuat dari ijuk menjulur ke bawah dan dilengkapi dengan mustoko. Kemudian tokoh tersebut mengajak warganya untuk bertani, berternak dan berkebun serta memberikan arahan tentang keyakinan terhadap 
Tuhan Yang Maha Esa. Tokoh tersebut juga membentuk kelompok yang dipimpin oleh juru kunci untuk mempermudah memberikan arahan/wejangan tentang sosial, budaya dan gotong royong (Nawawi, 2015, p. 24).

Sesepuh desa Bonokeling menyatakan bahwa di dunia ini manusia dalam melakukan pendekatan kepada yang kuasa itu "Menungsa urip teng dunya niku nek mboten nyantri nggih nyandi". Yaitu yang berarti bahwa, manusia hidup di alam dunia ini terbagi menjadi dua, "nyantri" dan "nyandi". Nyantri merupakan muslim dengan pengamalan rukun Islamnya yang lima secara utuh sedangkan nyandi merupakan kelompok muslim yang pengamalan rukun Islamnya hanya tiga (syahadat, puasa dan zakat), tanpa mengerjakan shalat lima waktu. Oleh karena itu istilah "nyantri" bisa dikatakan "Islam lima waktu", sedangkan istilah "nyandi” identik dengan " Islam tanpa shalat lima waktu". Adapun poros dari keyakinannya mendasarkan pada punden yaitu tempat-tempat suci. Tempat yang dianggap suci oeleh leluhur mereka dahulu yaitu makam Kyai Bonokeling.

Salah satu ajaran yang masih dijaga sampai sekarang adalah ritual unggahan yaitu upacara yang dilakukan oleh anggota komunitas Bonokeling untuk menyambut bulan suci Ramadhan dengan do'a dan zikir kepada Allah. Tata cara yang dajarkan oleh kyai Bonokeling tersebut hingga kini masih dilaksanakan oleh anggotanya. Ritual Unggahan ini biasanya dilakukan pada bulan Syaban atau dalam sebutan orang jawa bulan Sadran.

Pelaksanaan prosesi unggahan ini membutuhkan waktu yang cukup lama yaitu sekitar 2-3 hari, dikarenakan ritual unggahan ini merupakan ritual terbesar dan paling banyak dihadiri oleh anak putu Bonokeling. Bukan hanya anak putu yang berada di Desa Pekuncen saja akan tetapi semua anak putu yang berasal dari sekitar Banyumas dan banyak juga orang-orang yang datang dari luar kota turut mengikuti ritual ini. Menariknya ritual ini banyak diikuti oleh bermacam-macam kalangan mulai dari anak putu Bonokeling sendiri, peneliti kebudayaan, jurnalis, dan para mahasiswa.

Nilai-nilai kebersamaan dalam ritual ini sangat kental dikarenakan berbagai anak putu bersatu dan berbaur tanpa ada perbedaan. Mereka datang berbondong-bondong dari berbagai daerah khususnya Banyumas dan Cilacap, bukan hanya anak putu yang hadir dalam acara tersebut akan tetapi banyak pula dari masyarakat luas.

\section{Pemahaman Al-Qur'an Komunitas Bonokeling}

\section{Pandangan umum terhadap Al-Qur'an}

Masyarakat komunitas Bonokeling ini merupakan komunitas masyarakat adat yang masih memegang erat budaya Jawa, baik itu kepercayaan dalam keberagamaan ataupun hukum-hukum adat yang berlaku sejak zaman nenek moyang mereka. Perihal 
pedoman hidup yang mereka pegang pun sebagian besar merupakan pedoman dari nenek moyang mereka.

Mengenai Kitab suci yang mereka jadikan pedoman hidup, tidak seperti umat Islam pada umumnya, kitab suci yang mereka jadikan pedoman hidup bukanlah kitab suci Al-Qur'an. Kitab suci atau pedoman yang digunakan mereka merupakan Kitab Turki atau tuturing kaki (petuah-petuah nenek moyang) dalam menjalani kehidupan mereka.

Sebagai pedoman utama, mereka mempercayai tuture kyai atau kepala adat, yang mana petuah-petuah yang diberikan sang kyai merupakan hasil olah rasa dan hati dari sang kepala adat. Dapat dikatakan bahwa komunitas Bonokeling ini tidak menjadikan Al-Qur'an sebagai pedoman mereka. Namun hasil wawancara yang telah dilakukan dengan bapak Sumitro selaku kepala adat menyebutkan:

"Ya tiang sepuh niku kan sampe dengan apa, sampe meninggal saja disini ada kata-kata pertanyaan-pertanyaan pertanggung jawaban dunia misalkan itu kitab suci Al-Qur'an saja dipertanyakan, panutane sapa? Panutane kanjeng nabi Muhammad SAW ingkang ketingal petak lah niku sepuh senajane ora bisa mbaca niku pedoman tuntutan wis ana, nah niku karena ngakune meluk agamane Islam, pertanyaan alam kubur kan ya diikutna itu diikut sertakan itu. jadi pedoman hidup itu ada Al-Qur'an nya tapi tidak paham tapi ada jawanya tetep tuntunannya dunia akhirat pake ilmu jawa makannya ya itu yang tadi ngomong belajarnya dari ini dicocokkan dengan Al-Qur'an sebenarnya di Al-Qur'an itu ada tapi ini pakenya jawa. Lalu kitabnya apa pak? Ya makane disini disebutken kitab turki (pituture kaki) ya kaya gini mlakune mboten tertulis, dadi mbatin semuanya, tapi kan kalo kita ngapalna, kalo ada orang yang bisa ilmu sini bisa nangkep gitu lho maksudnya.

Dari pernyataan bapak Sumitro, yang dalam hal ini beliau merupakan kepala adat komunitas Islam kejawen Bonokeling bahwasannya mereka mempercayai adanya AlQur'an hanya saja mereka tidak memperlakukan Al-Qur'an sebagai mana umat Muslim pada umumnya. Umat Muslim pada umumnya membaca, mengahafal, atau menggali makna-makna yang terdapat dalam Al-Qur'an sesuai dengan fungsi al-Quran itu sendiri yaitu sebagai pedoman hidup umat muslim.

Komunitas Bonokeling ini tidak memposisikan Al-Qur'an sebagai pedoman hidup secara langsung karena mereka tidak bisa membacanya. Akan tetapi mereka tetap mempercayai atau meyakini bahwa Al-Qur'an merupakan kitab suci umat Islam. Adapun dari pernyataan pak Sumitro diatas karena mereka merupakan umat Islam yang meyakini ketika di alam kubur nanti akan ditanya mengenai Tuhan, Rasul, Kitab yang mereka yakini.

Kemudian mereka juga mempercayai bahwa apa yang mereka kerjakan tidak jauh berbeda dari apa yang diperintahkan oleh Al-Qur'an. Pak Sumitro mengambil kesimpulan tersebut dikarenakan setelah banyak para peneliti-peneliti dari luar salah satunya yang berasal dari LIPI (Lembaga Pemerintah Non Kementrian Republik 
Indonesia) yang mempelajari ajaran-ajaran ataupun tradisi-tradisi komunitas Bonokeling ini dan mencocokan dengan apa yang ada didalam Al-Qur'an ataupun ajaran Islam bahwa pada hakikatnya tujuan dari apa yang komunitas Bonokeling ini kerjakan sama dengan apa yang menjadi tujuan dari Al-Qur'an atau pada umumnya ajaran Islam itu sendiri. Akan tetapi perbedaan yang sangat mencolok dari ajaran Islam kejawen dengan Islam Puritan atau Islam yang menjadikan Al-Quran dan Al-Hadits sebagai pedoman adalah shalat lima waktu, karena mereka mempunyai definisi tersendiri terkait dengan sholat.

Menurut pak Sumitro kalau di masyarakat komunitas Islam Kejawen itu tidak shalat akan tetapi sembahyang dan sembahyang di komunitas tersebut bermakna sembah yang disini adalah:

Menyembah sanghyang widi merguna kan ngerukunaken umat tradisi guyub rukun rukun gotong royong meyembah saamyang widhi kalo semyang widhi itu tuhan yang maha esa makanya kadang kadang sgolat tiap hari bisa tidak bisa sembahyang karena tandanya nggak wawuh merga tidak rukun kan dadine. ${ }^{2}$

Menyembah Sanghyang Widi melestarikan dan merukunkan umat tradisi membuatnya rukun gotong royong menyembah sanghyang widhi atau Tuhan yang maha Esa maka dari itu terkadang orang-orang bisa sholat tiap hari tetapi tidak bisa sembahyang karena tandanya tidak kenal atau mengerti maka dari itu jadi tidak rukun.

\section{Implikasi terhadap kehidupan sehari-hari}

Berangkat dari cara pandang dan pemahaman mereka mengenai Al-Qur'an inilah kemudian membawa implikasi-implikasi terhadap kehidupan sehari-hari mereka. Masyarakat komunitas Islam kejawen ini mejadikan petuah nenek moyang sebagai tuntunan hidup hingga kini, dalam hal ini peneliti hanya memfokuskan dalam beberapa hal yang dianggap penting antara lain mengenai salat dan aurat:

\section{a. Pandangan Terhadap Salat}

Ibadah salat yang menjadi tiang agama Islam, memiliki makna dan interpretasi tersendiri bagi kalangan orang Islam kejawen. Shalat bagi kalangan orang Islam Kejawen menjadi rukun agama yang sangat penting, tidak hanya sebatas rukun Islam dan media membersihkan diri dari dosa, tetapi juga sebagai jalan mistik untuk mencapai manunggaling kawula Gusti. Ajaran salat sebagai jalan mistik ini dapat kita temukan dalam berbagai serat atau suluk, diantaranya adalah Suluk Sajatining Salat dan Suluk Salat Sarengat Tarekat Kakekat Makripat yang ditulis oleh Abdi Dalem Pangeran Sastrawijaya dari Kajoran (Khalim, 2011, p. 7).

\footnotetext{
${ }^{2}$ Wawancara dengan bapak Sumitro selaku kepala adat pada Jum'at 21 September 2018
} 
Suluk Sajatining Salat dan Suluk Salat Sarengat Tarekat Kakekat Makripat yang ditulis oleh Sastrawijaya secara singkat memberikan gambaran tentang makna salat bagi orang-orang Islam Kejawen, yaitu salat sebagai ngelmu dan laku, dan makna simbolisme gerakan salat. Salat sebagai ngelmu dan laku, oleh Sastrawijaya dilandaskan pada lafal niat salat (uṣalli), yang ditafsirkan secara falsafi untuk memperoleh makna terdalam (hakekat) dari kata-kata (lafal) niat sendiri. Kata uṣalli sebagai lafal niat salat, terdiri dari empat huruf (alif, șad, lam, dan ya atau alif layyinah), oleh Sastrawijaya diartikan bahwa huruf alif yang pertama merupakan perumpamaan manusia, dan huruf alif kedua merupakan perumpamaan Tuhan, yang menghimpit sifat dan zat Tuhan (huruf șad dan lam). Sifat dan zat Tuhan sebenarnya telah ada dan menyatu dalam diri manusia, sebagai sosok insan kamil (Khalim, 2011, p. 7).

Berbeda dengan pemaknaan dari komunitas Islam Kejawen Bonokeling, Menurut pak Sumitro kalau di masyarakat komunitas Islam Kejawen Bonokeling itu tidak mengistilahkan salat akan tetapi sembahyang dan sembahyang di komunitas tersebut bermakna Sembah yang disini adalah:

Menyembah sanghyang widi merguna kan ngerukunaken umat tradisi guyub rukun rukun gotong royong meyembah saamyang widhi kalo semyang widhi itu tuhan yang maha esa makanya kadang kadang sgolat tiap hari bisa tidak bisa sembahyang karena tandanya nggak wawuh merga tidak rukun kan dadine. ${ }^{3}$

Menyembah Sanghyang Widi melestarikan dan merukunkan umat tradisi. Yang membuat rukun gotong royong adalah menyembah Sanghyang Widhi atau Tuhan yang maha Esa, sehingga kadang-kadang orang bisa sholat tiap hari tetapi tidak bisa sembahyang. Itu tandanya dia tidak kenal atau mengerti maka itu jadi tidak rukun.

Perbedaan-perbedaan pemaknaan antara Islam kejawen pada masa kekeratonan dan Islam kejawen yang ada di desa Pekuncen Jatilawang ini sangatlah berbeda. Perbedaan diantara keduanya itu memunculkan banyak kemungkinan, yang dalam hal ini kondisi politik dan sosial historis pada saat penyebaran ajaran Islam di desa ini sangatlah mempengaruhi kondisi tersebut. Akan tetapi sangat disayangkan karena sejarah mengenai komunitas Bonokeling khususnya mengenai tokoh Kyai Bonokeling yang masih sebatas asumsi dan belum bisa dilacak dengan pasti inilah yang menyebabkan penelusuran mengenai ajaran mereka belum bisa dipastikan kebenarannya.

\section{b. Pandangan Terhadap Aurat}

Aurat menurut bahasa adalah sesuatu yang menimbulkan rasa malu, sehingga seseorang terdorong untuk menutupnya (Poerwadarminta, 1984, p. 65). Secara terminologi dalam Hukum Islam, aurat adalah bagian badan yang tidak boleh kelihatan

\footnotetext{
${ }^{3}$ Wawancara dengan bapak Sumitro selaku kepala adat pada Jum'at 21 September 2018
} 
menurut syariat Islam, batas minimal bagian tubuh manusia yang wajib ditutupi berdasarkan perintah Allah. Berdasarkan pengertian ini, dipahami bahwa aurat tidaklah identik dengan bagian tubuh yang ditutup menutut adat suatu masyarakat (Sesee, 2016, p. 316).

Pada dasarnya tidak ada perselisihan mengenai kewajiban menutup aurat akan tetapi yang banyak dipermasalahkan adalah batasan-batasan yang diberlakukan pada setiap individu. Berdasarkan syari'at, sebagaimana yang disebutkan dalam Al-Qur'an dan Hadits, maupun ijtihad ulama.

Jumhur Ulama sepakat bahwa aurat wanita yang wajib ditutup ketika bershalat adalah segenap anggota tubuhnya, kecuali muka dan telapak tangan nya. Muka dan dua telapak tangan itu, menurut Sayyid Sabiq adalah bagian tubuh yang diperbolehkan tampak sesuai dengan kaliamat illā mā zahara minhā dalam QS. An-Nur (24): 31. Adapun aurat ketika berhadapan dengan non-muhrim, para fuqaha pun memiliki pandangan yang berbeda-beda ada yang berpendapat bahwa aurat yang boleh terlihat saat shalatlah yang boleh terlihat oleh selain muhrim (Sesee, 2016, p. 317).

Al-Qurtubi mengatakan bahwa menurut kebiasaan adat dan ibadah dalam Islam, wajah dan dua telapak tangan itulah yang biasanya kelihatan, sehingga pengecualian dalam ayat 31 surah An-Nur merujuk kepada dua bagian tubuh tersebut. Selain dari itu wajib ditutup, berdasarkan pula satu riwayat dari Asma binti Abu bakar bahwa ia pernah ditegur oleh Rasulullah SAW;

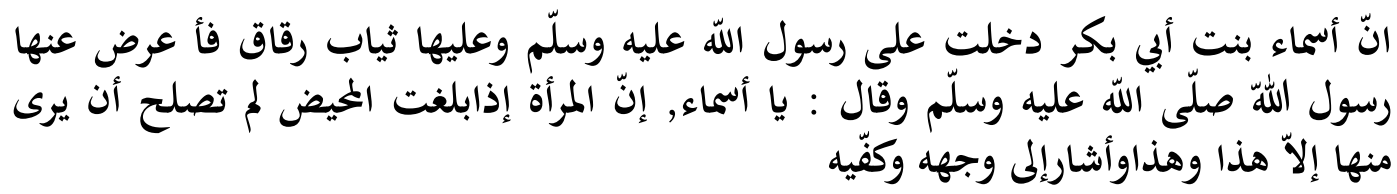

"Hai Asma", sesungguhnya wanita yang sudah baligh tidak boleh tampak dari badannya kecuali ini, lalu rasul menujuk wajah dan dua telapak tangannya"4

Nashr Hamid Abu Zaid menegaskan kenyataan yang menunjukkan bahwa teks Al-Qur'an senantiasa mempunyai hubungan dialektika dengan masyarakat Arab di masa pewahyuan merupakan hal nyata yang memberikan pengertian bahwa secara tidak langsung teks Al-Qur'an dibentuk oleh realitas peradaban Arab yang ada di satu sisi, namun di sisi lain juga teks Al-Qur'an berperan dalam perombakan peradaban lewat pesan atau konsep-konsep yang ditawarkan dari Al-Qur'an itu sendiri. Bahwa AlQur'an terbentuk dalam suatu budaya tertentu inilah yang menjadikan beberapa pembahasan dalam Al-Qur'an tidak sertamerta dapat diambil secara mentah, celah yang kemudian membuka berbagai ijtihad dari para ulama maupun intelektual atas beberapa

\footnotetext{
${ }^{4}$ Dari Aplikasi Gawamiul Kalem, Sunan Abu Daud, HR. Abu Daud No. 3580.
} 
pembahasan. Akan tetapi di sisi lain Al-Qur'an pula pembentuk pesan-pesan, yang secara tidak langsung membentuk pandangan secara umum dari umat muslim.

Jika kita mengambil tafsiran dari Quraish Shihab mengenai kewajiban menutup aurat dalam QS.An-Nur ayat 31 yaitu:

Katakanlah kepada wanita yang beriman: "Hendaklah mereka menahan pandangannya, dan kemaluannya, dan janganlah mereka Menampakkan perhiasannya, kecuali yang (biasa) nampak dari padanya. dan hendaklah mereka menutupkan kain kudung kedadanya, dan janganlah Menampakkan perhiasannya kecuali kepada suami mereka, atau ayah mereka, atau ayah suami mereka, atau putera-putera mereka, atau putera-putera suami mereka, atau saudara-saudara lakilaki mereka, atau putera-putera saudara lelaki mereka, atau putera- putera saudara perempuan mereka, atau wanita-wanita Islam, atau budak- budak yang mereka miliki, atau pelayan-pelayan laki-laki yang tidak mempunyai keinginan (terhadap wanita) atau anak-anak yang belum mengerti tentang aurat wanita. dan janganlah mereka memukulkan kakinyua agar diketahui perhiasan yang mereka sembunyikan. dan bertaubatlah kamu sekalian kepada Allah, Hai orang-orang yang beriman supaya kamu beruntung.

Beliau memaknai perintah untuk mengenakan jilbab bagi Muslimah pada ayat diatas sebagai budaya dari masyarakat Arab. Maka jilbab dikatakan tidaklah wajib dalam konteks keindonesiaan. Karena menurut beliau ayat dalam Al-Qur'any ang menjelaskan kewajiban untuk seorang muslim menggunakan jilbab merupakan kewajiban yang dinilai mengandung unsur-unsur budaya dari bangsa arab. Sehingga dengan konteks sosial yang berbeda menurut beliau tidaklah diwajibkan bagi muslimah Indonesia untuk memakai jilbab. Pandangan Quraish Shihab mengenai jilbab dalam konteks keindonesiaan tersebut selaras dengan pandangan dari Nashr Hamid Abu Zaid bahwasnnya teks Al-Qur'an harus dimaknai sesuai konteks ayat tersebut diaplikasikan (Azmyannajah, 2016, p. 123).

Komunitas Islam Kejawen memiliki pemahaman tersendiri mengenai konsep aurat yang diwariskan oleh nenek moyang mereka. Pemahaman nenek moyang yang masih kental dengan tata aturan dan tradisi Jawa Hindu-Budha. Corak Islam yang sangat kental akan nuansa Kejawen inilah yang menjadikan tradisi-tradisi yang mereka jalankan sangat erat dengan tradisi Jawa Hindu-Budha seperti sembahyang, sadran, perlon dan lain sebagainya.

Dalam ritual unggahan misalnya, unggahan merupakan ritual yang dilaksanakan setahun sekali untuk menyambut bulan suci Ramadhan. Ada beberapa hal menarik untuk dikaji terkait syarat-syarat dalam ritual unggahan ini, diantaranya dalam hal busana. Para peserta yang akan mengikuti upacara ini harus mengenakan pakaian adat jawa untuk laki-laki seperti jarit atau kain batik panjang, berpakaian hitam panjang, dan mengenakan udeg-udeg atau semacam blangkon. Kemudian untuk perempuan mengenakan jarit, berpakaian hitam panjang tidak boleh memakai penutup kepala dan 
dibeberapa tahapan ritual perempuan harus melepas baju hitam dan hanya menggunakan kemben.

Mengenai alasan kenapa peserta wanita tidak boleh menggunkan jilbab, dibawah ini merupakan hasil wawancara dengan pak sumitro selaku kepala adat.

"Njih mboten, pas acara niku dilepas, ya karena menunjukkan bahwa orang jawa itu harus mengetahui jawanya asli, nah ini kan termasuknya sebelum Islam kemudian jilbab kan sesudah adanya Islam. nah tradisi ini sudah ada sebelum Islam datang, kita masih tetap memakai polos kejawennya ditunjukkan itu kita memakaai kebaya jarit ciri khas orang jawa kan seperti itu dulu. Makanya misalnya ada aanak-anak yang mau ziarah kemakan ya harus kita lepas kalau mau kesana harus pake tapih nggk pake celana harus pake kebaya harus adat jawa makanya orang laki-laki seperti ini (sambil menunjukkan apa yang beliau pakai yaitu baju ciri khas orang jawa disertai dengan blangkon) kalau setelah itu nanti selesai itu boleh dipakai lagi paling pas saat itu karena disitu naik kesana karena disitu nanti ada wudhu kita harus pasrah sesuaikan dengan alam itu tidak boleh ditutup-tutupi karena kita asalnya tanah kembali ketanah. Jadi kita menyesuaikan alam itu juga termasuk ada kayu ada apa gitu."

Bahwasannya masyarakat komunitas Bonokeling ini masih sangat memegang erat adat Jawa terlihat dari pernyataan-pernyataan yang diberikan oleh pak Sumitro mengenai alasan kenapa para peserta ritual unggahan ini harus memakai pakaian adat dan melarang peserta wanita yang mengenakan jilbab untuk mengikuti ritual ini. Mereka beranggapan bahwa "orang Jawa itu harus mengetahui Jawanya asli". Itu artinya bahwa mereka harus kembali kebiasaan-kebiasan atau tradisi-tradisi Jawa yang sudah ada sejak zaman dahulu. Dan pula pak Sumitro meyebutkan "kita harus pasrah sesuaikan dengan alam itu tidak boleh ditutup-tutupi karena kita asalnya tanah kembali ke tanah. Jadi kita menyesuaikan alam." Bahwasannya atas dasar filosofis tersebut terbangun. Tidak menurut mereka jilbab atau lebih khususnya Islam datang sesudah adanya Jawa atau Hindhu-Budha, sehingga mereka lebih memilih untuk melestarikan warisan nenek moyang mereka yaitu dengan tetap menggunakan pakaian adat dalam semua ritual-ritual yang dilaksanakan.

Sedangkan menurut ibu-ibu yang dari golongan masyarakat biasa, mereka tidak menggunakan jilbab karena nenek moyang mereka tidak memerintahkan untuk memakai jilbab. ${ }^{6}$ Dalam struktur sosial masyarakat Islam Kejawen ini wanita tidak memiliki hak untuk sekedar menanyakan kenapa hal tersebut menjadi sebuah ketentuan. Karena wanita-wanita komunitas Bonokeling bahkan istri dari ketua adatpun tidak mengerti mengapa hal tersebut dijadikan sebuah ketentuan atau tradisi yang harus dilaksnakan oleh semua anggota komunitas Islam kejawen. Para wanita anggota komunitas Islam kejawen ini beranggapan bahwa tugas wanita hanya mengikuti apa

\footnotetext{
${ }^{5}$ Wawancara dengan bapak Sumitro selaku ketua adat pada Minggu 11 November 2018

${ }^{6}$ Wawancara dengan ibu Atmo selaku anggota komunitas Islam kejawen Bonokeling, Pada Jum'at 21 September 2018
} 
yang diperintahkan oleh suami dalam lingkup keluarga dan juga kepala adat dlam lingkup komunitas.

Menurut pak Sumitro selaku ketua adat bahwasannya jilbab itu tidak begitu mempengaruhi diri seseorang, karena segala sesuatu itu tergantung hatinya, walaupun badannya tertutupi semua tapi hatinya jelek atau jahat akan percuma. Jadi walaupun terkadang tidak berpendirian dalam berpakaian atau dalam sesuatu yang bersifat fisik tetapi yang terpenting hatinya tetap teguh yakin kepada Allah SWT. Karena pada dasarnya mereka meyakini sorga neraka ana nang awake dewek.

Menurut penuturan pak Sumitro;

"Surga neraka itu ada ning atine dewek arep perbuatan apik ya ning dewek, ala ya ning dewek sorga neraka ning awake dewek iya kan? Iya monggo arep dituku karo zakat nggo bayaran sorga masa bisaha karena malaikat sudah mncatat lagu sehari-hari iya kan? Kalo kepercayaan mriki percaya malekat malekate dewek lho ora malekat ngko nang kan, itu nek carane wong jawa arane kie cahaya mata dua itu malekat. Setan niku anane nang awake dewek lha kui kudu terhindarkan. Napsu anane nag awak dewek."

"Surga neraka itu ada didalam hati masing-masing orang, apakah itu perbuatan baik nantinya akan kembali kepada diri kita sendiri, keburukan juga akan kembali ke diri seseorang tersebut surga neraka dalam diri masing-masing iya kan? Ia solahkan mau dibeli dengan zakat untuk membeyar surga tidak akan bisa karena malaikat sudah mencatat perilaku kita setiap hari iya kan? Kalau kepercayaan disini, percaya kepada malaikat akan tetapi malaikatnya sendiri bukan malaikat nanti disana, itu kalau menurut orang jawa bahwa cahaya mata kita atau mata seseorang it merupakan malaikat. Setan itu adanya dalam diri manusia dan itu harus dihindarkan, nafsu ada dalam diri seseorang."

Mereka meyakini bahwa surga dan neraka itu ada dalam hati atau diri seseorang, malaikat sudah mencatat perbuatan manusia setiap harinya. Adapun malaikat menurut mereka adalah kedua mata yang dimiliki manusia jadi istilahnya malaikat itu adalah diri sendiri, dan setan juga ada didalam diri dan itulah yang harus dihindarkan, dan seharusnya diri kita sendirilah yang bisa menahan diri dari perbuatan-perbuatan dosa.

Menurut kepala adat komunitas Bonokeling ketika ibu-ibu yang sudah tua kemudian memakai jilbab itu kesannya "wagu” (tidak pantas) karena menurut pak Mitro segala sesuatu itu seharusnya dimulai sejak kecil dan bertahap kalo mengikuti ketika sudah tua itu istilah jawanya "wis tua cemang-cemong jilbabab wagu" (sudah blepotan malah jilbaban tidak pantas). Ketidakpantasan itu karena adanya ketidaksesuaian antara yang nampak secara fisik dan yang tidak nampak atau dalam hal ini ilmu yang dimilki oleh seseorang tersebut.

Contoh menggunakan jilbab rapih, baik, cantik tapi mereka tidak menjalankan syariat Islamnya misalnya seseorang disuruh untuk membaca kalimat syahadat dan

\footnotetext{
${ }^{7}$ Wawancara dengan bapak Sumitro selaku ketua adat pada Jum'at 21 September 2018

${ }^{8}$ Wawancara dengan bapak Sumitro selaku ketua adat pada Jum'at 21 September 2018
} 
gelagapan karena tidak bisa, jadi tidak sebatas untuk menutupi aurat luar saja batin pun perlu juga dibrongsong (dibungkus) dan tidak boleh dilupakan. Akan tetapi bahwa tidak bisa dipungkiri bahwa jilbab itu benar untuk menutupi aurat itu betul tetapi aurat bukan hanya fisiknya saja tetapi batinnya perlu ada penerang juga. Lalu pak sumitro menegaskan bahwasannya menurut kepercayaan Islam kejawen di komunitas Bonokeling ketika mereka disuruh untuk menutupi aurat mereka beranggapan bahwa memakai jilbab itu harus batinnya terlebih dahulu sehingga orang tidak tertipu dengan penampilan luar kita, dan antara yang nampak dan yang tidak akan selaras.

Secara umum implikasi dari pandangan umat Islam terhadap keberislaman di masyarakat Islam sangat kentara dimana mereka tidak sepenuhnya melaksanakan apa yang disyariatkan dalam ajaran Islam, misalnya mereka tidak melaksanakan shalat begitu juga rukun Islam yang lain, sang kepala adat hanya mewajibkan anggota dari komunitas Islam kejawen untuk melaksanakan rukun iman saja. Mereka mejadikan petuah nenek moyang sebagai tuntunan hidup hingga kini. Sehingga dengan pandanganpandangan tersebut mengakibatkan implikasi yang berbeda dalam kehidupan sehari-hari mereka.

\section{Simpulan}

Dari pemaparan diatas dapat kita simpulkan bahwa; Pertama, komunitas Islam kejawen ini merupakan salah satu komunitas Islam kejawen yang masih memegang erat tradisi-tradisi nenek moyang mereka. Oleh pemerintah komunitas ini ditetapkan sebagai aliran keyakinan bahkan makam Kyai Bonokeling telah diresmikan sebagai kawasan cagar budaya oleh pemerintah. Kedua, Komunitas Islam kejawen yang bisa dikatakan sinkretis ini memiliki pandangan atau pemahaman tersendiri mengenai Al-Qur'an. Mereka tidak menggunakan Al-Qur'an sebagai pedoman hidup layaknya umat Islam pada umumnya. Mereka hanya meyakini Al-Qur'an sebagai kitab suci yang kelak di alam kubur akan ikut dipertanyakan oleh malaikat, sehingga dengan pandangan tersebut membawa implikasi dalam kehidupan praksis mereka. Contohnya pandangan mereka mengenai shalat, mereka mengistilahkan shalat sebagai sembahyang yang dalam segi definisi pun memiliki definisi yang berbeda dengan shalat bagi umat Islam pada umumnya. Ketiga, mereka memaknai sembahyang sebagai berbuat baik kepada sesama manusia, rukun, saling tolong menolong dan menjaga tradisi nenek moyang mereka. Keempat, sedangkan dalam memaknai aurat, mereka tidak memiliki batasan-batasan anggota tubuh yang wajib ditutup akan tetapi mereka menekankan bahwa yang terpenting adalah memperbaiki diri terlebih dahulu karena menurut mereka akan percuma ketika diluar terlihat baik sedangkan di dalam diri seseorang tersebut masih belum baik. 


\section{E. Daftar Pustaka}

Abu Zayd, N. H. (1993). Mafhūm al-Nash: Dirāsāt fì 'Ulūm al-Qur'ān. Kairo: alHay’ah al-Mishriyyah al-‘Āmmah li Alkitāb.

Azmyannajah, G. (2016). Penafsiran Ayat-Ayat Tentang Aurat Dalam Al-Qur'an (Studi Komparatif Tafsir Al-Misbab dan Al-Azhar) (Skripsi). Fakultas Ushuluddin UIN Sunan Kalijaga, Yogyakarta.

Berger, P. L. (1991). Langit Suci :Agama Sebagai Realitas Sosial. Jakarta: LP3ES.

Berger, P. L., \& Luckman, T. (2012). Tafsir Sosial Atas Kenyataan Risalah Tentang Sosiologi Pengetahuan (H. Basari, Trans.). Jakarta: LP3ES.

Izutsu, T. (1995). Etika Keberagaman dalam Al-Qur'an. Jakarta: Pustaka Firdaus.

Khalim, S. (2011). Salat dalam Tradisi Islam Kejawen. Sabda, VI(1), 7.

Muslim, S. (2018). Memasyarakatkan Alqurandi Era Globalisasi. Yogyakarta: MUI Gunung Kidul.

Muttaqin, A. (2017). Sejarah Islamisasi Banyumas [Penelitian]. Purwokerto: IAIN Purwokerto.

Nawawi, N. (2015). Tradisi Unggahan Sebagai Transformasi Agama, Sosial dan Budaya [Penelitian]. Purwokerto: IAIN Purwokerto.

Poerwadarminta. (1984). Kamus Umum Bahasa Indonesia. Jakarta: PN Balai Pustaka.

Purwana, B. H. S. (2015). Sistem Religi Komunitas Adat Bonokeling, di Desa Pekuncen, Kecamatan Jatilawang, Kabupaten Banyumas. Yogyakarta: Kepel Press.

Sesee, M. S. (2016). Aurat Wanita dan Hukum Menutupnya Menurut Hukum Islam. Jurnal Al-Maiyyah, IX(2).

Tajuddin, Y. (2014). Walisongo Dalam Strategi Komunikasi Dakwah. Addin, VIII(2), 365. 